\title{
INOVAR AUTO PROGRAM: ENERGY EFFICIENCY ANALYSIS FOR FLEX FUEL ENGINES.
}

Marcos Vinicius Ribeiro ${ }^{a}$, Rafael Guimarães O. dos Santos ${ }^{a}$, Thiago B. Muraria ${ }^{\text {, Aloísio }}$ S. Nascimento Filho ${ }^{a}$

a SENAI CIMATEC, Brasil

\begin{abstract}
The Inovar Auto Program, was the Incentive Program for Technological Innovation and Densification of the Automotive Vehicle Production Chain created to stimulate the production of vehicles with improvements in energy efficiency. This study aims to analyse the effectiveness of the program, it's improvement in vehicles with different motorization and the variation of energy consumption throughout the years that the program was in force. In order to make a statistical analysis, a systematic comparison of vehicle data available in public institutions. The statistical analysis showed that participating companies achieved gains in energy efficiency. Further research is needed to identify other factors related to energy consumption, as for example, the relation between energy consumption and gas emissions.
\end{abstract}

Keywords: Inovar Auto; Efficiency; Energy Consumption; Statistical Analysis.

\section{PROGRAMA INOVAR AUTO: ANÁLISE DE EFICIÊNCIA ENERGÉTICA PARA MOTORES FLEX FUEL.}

Resumo: O Programa Inovar Auto, foi o Programa de Incentivo à Inovação Tecnológica e Densificação da Cadeia Produtiva de Veículos Automotores criado para estimular a produção de veículos com melhorias na eficiência energética. Este estudo visa analisar a eficácia do programa, a sua melhoria em veículos com diferentes motorizações e a variação do consumo de energia ao longo dos anos de vigência do programa. Para a realização de uma análise estatística, foi realizada uma comparação de dados de veículos disponíveis em instituições públicas. A análise mostrou que houveram ganhos em eficiência energética. Pesquisas futuras podem ser realizadas para identificar outros fatores relacionados ao programa como por exemplo um estudo sobre as emissões de gases poluentes.

Palavras-chave: Inovar Auto; Eficiência; Consumo Energético; Análise Estatística. 


\section{INTRODUCTION}

The Inovar Auto program was created by Law No. 12,715 / 2012, the Incentive Program for Technological Innovation and Densification of the Automotive Vehicle Production Chain and was the Brazilian Government's automotive regime through the years of 2013 to 2017, which aimed to create conditions to increase competitiveness in the automotive sector, production of more economical and safer vehicles, investments in the supply chain, in engineering, basic industrial technology, research and development and training of suppliers. [1]

Among the specific goals of the program was the production of more economical vehicles. As benefits for the companies participating in the program, starting from 2017, gains in energy efficiency improvement above $15.46 \%$ were entitled to a reduction of one percentage point of IPI (Tax on Industrialized Products) and improvements above $18.84 \%$ were entitled to a reduction of two percentage points of IPI.

Companies that produced vehicles in the country were able to participate in the Inovar Auto program; companies that did not produce, but sold vehicles in the country and companies that presented an investment project for vehicle production in the country were also able to participate. During its five years of term, a total of 27 manufacturing companies, 15 importing companies and 19 new investment projects were qualified.

The research question that guides this study is: Were there any real gains in the production of more economical vehicles from the Inovar Auto program? Analyzing energy consumption by type of engine for 1.0 engines; $1.4 ; 1.51 .6 ; 1.8$ and 2.0 cylinder capacity using two fuels, flex fuel engines. As part of the research, engines 1.2 and 1.3 were not evaluated because there are not many vehicles produced with this engine.

\subsection{Energy Efficiency}

Energy efficiency is measured by "levels of autonomy expressed in kilometers per liter of fuel $(\mathrm{Km} / \mathrm{I})$ or levels of energy consumption expressed in megajoules per kilometer $(\mathrm{MJ} / \mathrm{Km})$, measured according to rules established in the Program's legislation" [2].

In the Inovar auto program, the energy efficiency indicator was used, which was measured by the percentage of increase from the base year 2011. In 2011 the baseline in energy consumption for a vehicle, taking as reference, with a mass of $1121 \mathrm{Kg}$ was of $2.07 \mathrm{MJ} / \mathrm{Km}$ and as a challenge the companies participating in the program needed to reach the mandatory reduction target to $1.82 \mathrm{MJ} / \mathrm{Km}(12.08 \%)$ by November 1 , 2017. If this percentage was not reached it could occur the application of fines provided for in the legislation, in amounts proportional to the non-compliance with the established minimum goal.

For the purpose of verifying the achievement of the minimum target and targets for the reduction of the IPI, the average mass of vehicles in running order, in $\mathrm{kg}$, of all vehicles with flex-fuel motorization of the categories marketed by the qualified 
company is considered, weighted by the respective license plates that occurred in Brazil in the twelve months prior to the calculation. [3]

\subsection{Brazilian Vehicle Labeling Program}

According to [2] the Brazilian Labeling Program (PBE), coordinated by Inmetro, provides information on the performance of products, considering attributes such as energy efficiency, noise and other criteria that can influence the choice of consumers who, thus, will be able to make more informed purchasing decisions. The program also encourages the competitiveness of the industry, which should manufacture increasingly efficient products.

In the case of vehicles, the Brazilian Vehicle Labeling Program (PBE-V) aims to contribute to the choice of consumers when purchasing products more consciously. The program evaluates and makes available annually tables that present the energy consumption data of light weighted vehicles, from 2009 to 2020, approved in the Brazilian Labeling Program (PBE) and that, therefore, are authorized to own the National Energy Conservation Label ( ENCE).

\section{METHODOLOGY}

To answer the research, the methodology implemented consisted of: Review of the theoretical-conceptual literature on energy efficiency; Collection of data on the Inovar-Auto Program to identify the rules relevant to the program; Download of the PBE-V tables and subsequent calculations considering energy consumption in $\mathrm{MJ} / \mathrm{km}$ for flex-fuel engines and type of engine

To assess whether there was an improvement in energy efficiency, a reduction in the value of energy consumption $\mathrm{MJ} / \mathrm{Km}$, a consultation was made on the official autonomy data provided by the Brazilian Vehicle Labeling Program - PBE-V created by the National Institute of Metrology, Quality and Technology - INMETRO.

From the data available in the tables provided on the Inmetro website, statistically analyzing values in the period from 2013 to 2019 [4]. The analyzes comprise calculations of medians, quartiles and interquartile distances that aimed to provide comparative data to answer the research question.

\section{RESULTS AND DISCUSSION}

Initially, the energy consumption indices ( $\mathrm{MJ} / \mathrm{Km}$ ) were sought for all flex fuel engines and applying Box Plot methodology, Figure 1 was obtained. 
Figure 1 - Box Plot - Energy Consumption $(\mathrm{MJ} / \mathrm{Km})$ x Year

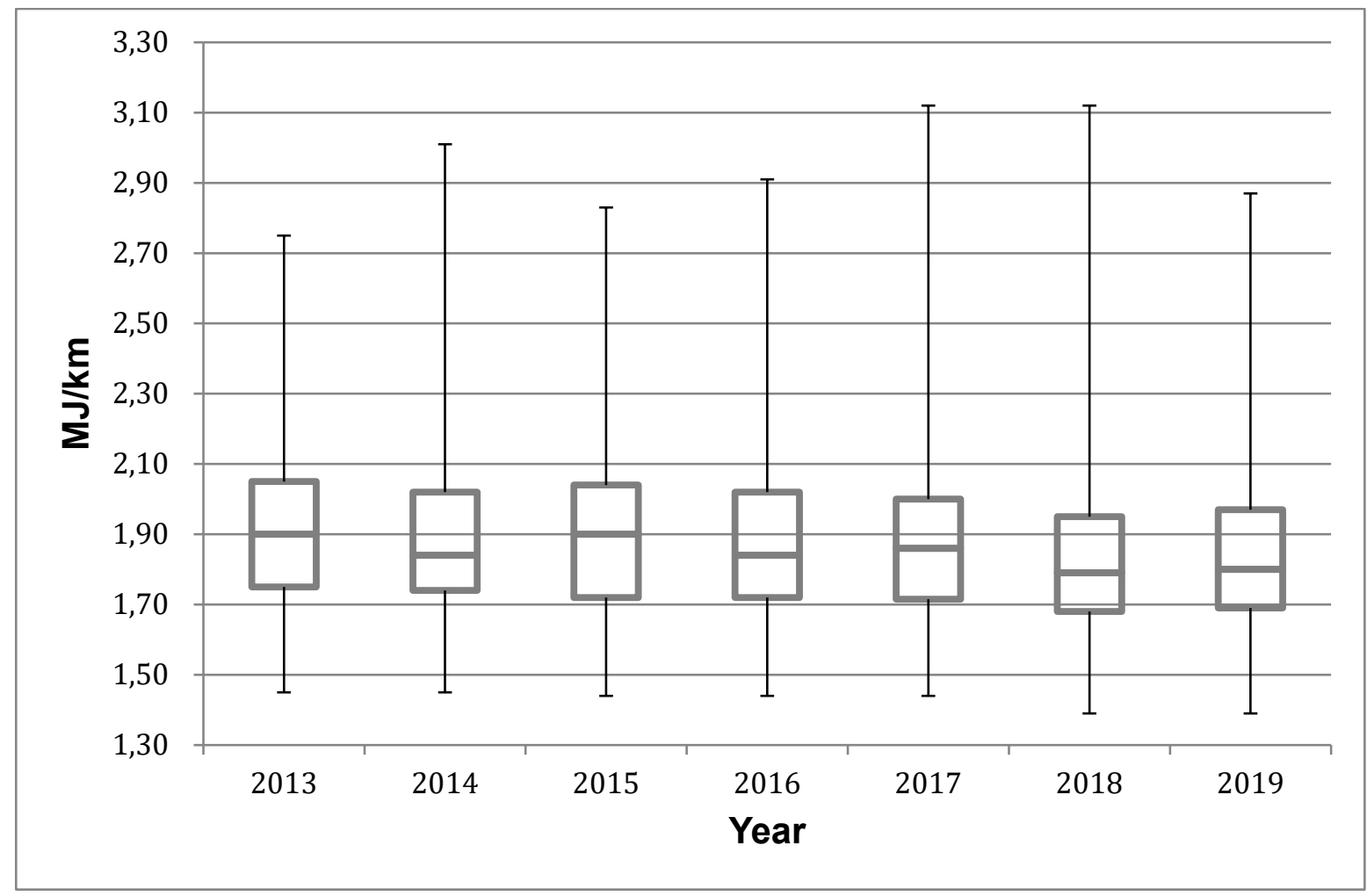

Source: Authors

Through figure 1 , it is verified year by year that the median value of energy consumption is reduced and lower the consumption, the better the energy efficiency, the exception is in the year 2014 to 2015 where there was an increase in energy consumption. Figure 1 shows as maximum outliers in the years 2017 and 2018 the consumption of $3.12 \mathrm{MJ} / \mathrm{km}$ and minimum values in the years 2018 and 2019 vehicles that presented consumption of $1.39 \mathrm{MJ} / \mathrm{km}$. Analyzing the amplitude of the collected data, figure 1 , the variation between the minimum and maximum values of the sample and sharp curves is verified. In order to disregard outliers, the interquartile distance was analyzed for figure 1 , obtaining table 1 and figure 2.

Table 1 - Amplitude and interquartile distance

\begin{tabular}{|l|c|c|c|c|c|c|c|}
\cline { 2 - 7 } \multicolumn{1}{c|}{} & 2013 & 2014 & 2015 & 2016 & 2017 & 2018 & 2019 \\
\hline Amplitude & 1,3 & 1,56 & 1,39 & 1,47 & 1,68 & 1,73 & 1,48 \\
\hline $\begin{array}{l}\text { Interquartile } \\
\text { Distance }\end{array}$ & 0,3 & 0,28 & 0,32 & 0,30 & 0,29 & 0,27 & 0,28 \\
\hline
\end{tabular}


Figure 2 - Amplitude $\mathrm{x}$ interquartile distance

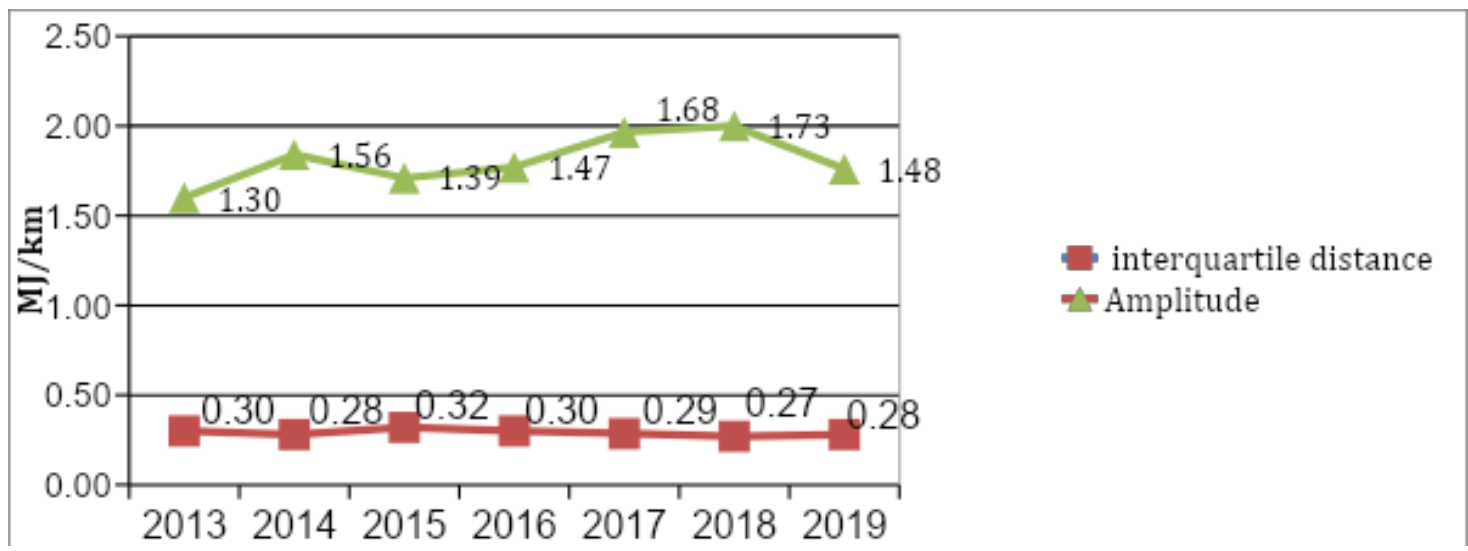

Source: Authors

In figure 2, the curve that represents the amplitude brings a great variation from one year to another if compared to the interquartile distance that presents something close to a straight line.

\subsection{Analysis by engine}

The data collected were divided by the motorization of the vehicles in relation to the cylinder capacity. And year of manufacture, analyzing the engines already mentioned in the methodology and data collected in the PBE-V, Figure 3 was obtained.

Figure 3 - Average energy consumption per year and per engine

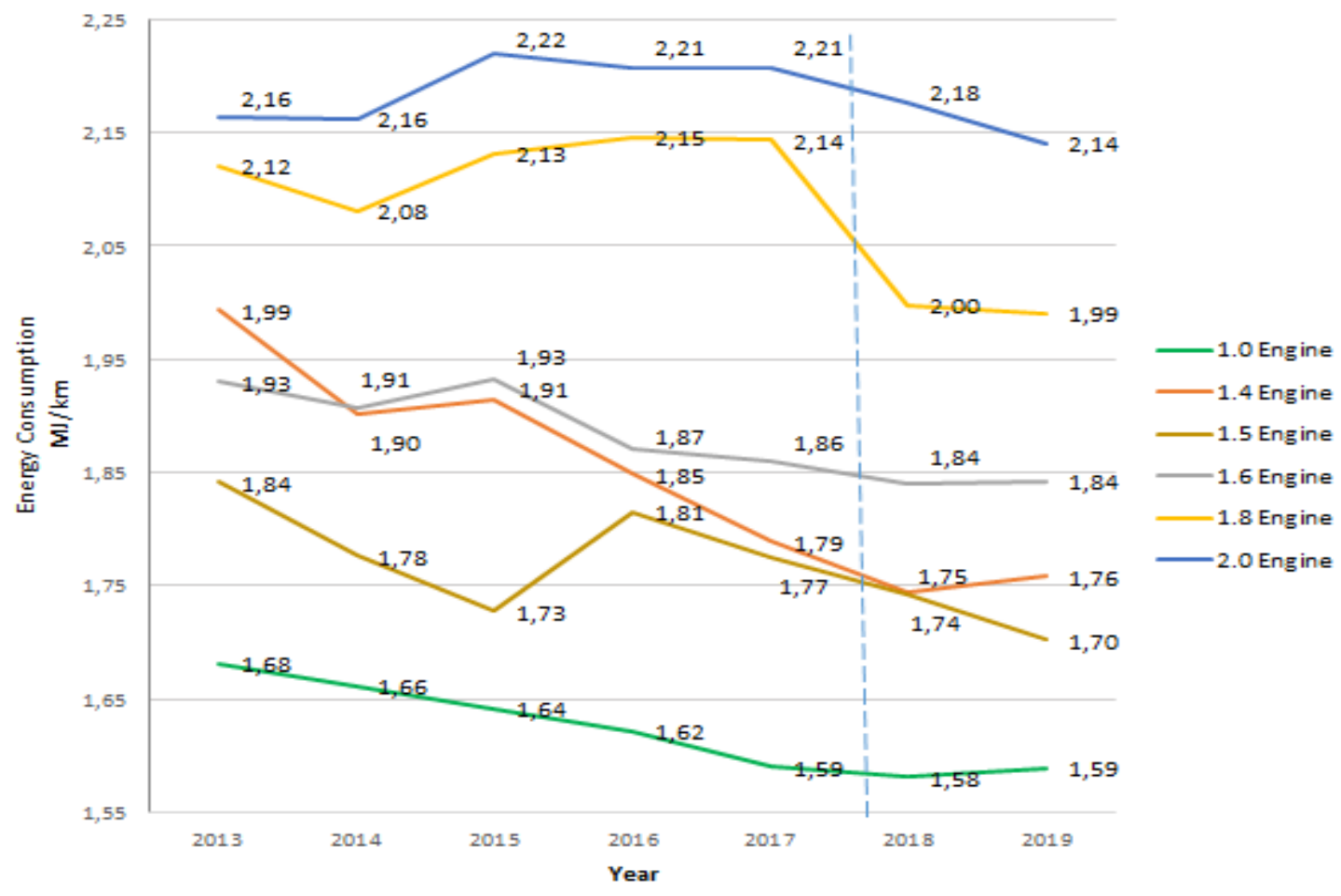

Source: Authors 
Figure 3 presents the consumption data year by year grouped by engine capacity and shows different curves for each model.

In 1.0-liter engines, it can be seen that there were improvements from 2013 to 2019, reducing energy consumption. Engines greater than 1.0 had an increase in energy efficiency at the beginning of the Inovar Auto program, a downward curve, but in 2014 and 2015 there was an increase in energy consumption, an upward curve. This fact is supposed to have occurred due to the change in consumer preference for Sport Utility Vehicle - SUV, which have a higher mass in running order, causing greater energy consumption.

From 2013 to 2017, there was a clear change in the profile of consumer preference, with the launch of numerous SUV vehicles, notably of greater mass, impacting the calculations of $\mathrm{MJ} / \mathrm{Km}$ [5]. It can be seen in figure 3 that in the year 2016 and close to the end of 2017, the energy improvement had a greater increase, downward curves, giving the idea that manufacturers took advantage of the Inovar Auto program to present the results of research and innovation in engines and other items that affect energy consumption.

Another point of analysis in figure 3, is the dashed vertical bar that indicates the end of the Inovar-Auto program in 2017. It is observed that even after the end of the program, vehicles with lower energy consumption continued to be manufactured, mainly for vehicles with lower energy consumption. engines larger than $1000 \mathrm{cc}$, where there are more opportunities for improvement for manufacturers than in vehicles with 1.0 engines that tend to stabilize their consumption at the level presented, unless new incentive policies are applied. After the end of the program, a certain stabilization of the energy consumption values is observed, except for 1.5 engines that continued to show small improvement values.

\section{CONCLUSION}

The results of the empirical study, based on data samples from INMETRO, pointed out the importance of the Inovar Auto program as evidenced by statistical analysis. As demonstrated by the evolution of the years 2018 and 2019, even after the end of the program, we can observe the continuity in the energy efficiency process. In addition, with the insertion of new models, SUVs with greater mass, it was found that the developments of more efficient engines were maintained.

Also, to continue the development of more efficient vehicles and with better engines, government plans to implement the program Rota 2030 in next few years, that aims to continue the improvements vehicle industries had with Inovar Auto, tax breaks to invest in R\&D and define security itens that will become mandatory as well.

The program represented an important milestone in the process of continuous improvement in energy efficiency, so that the automakers apparently perceived an opportunity to intensify their development.

Future deeper studies on energy efficiency through the analysis of energy efficiency by vehicle model will be required in order to better understand the 
evolutionary process of the Brazilian vehicle market and your changes throughout the years.

\section{REFERENCES}

[1] BRASIL, Ministério da Economia 2020. Available at: $<$ http://www.mdic.gov.br/index.php/competitividade-industrial/setorautomotivo/inovar-auto> Accessed on: 05 Jul. 2020.

[2] , Programa Brasileiro de Etiquetagem. Available at: <https://www2.inmetro.gov.br/pbe/conheca_o_programa.php> Accessed on: 17 Jul. 2020.

[3] Almeida Filho, Gilberto - Programa Inovar-Auto: Atendimento das metas de eficiência energética e suas externalidades / G. Almeida Filho -- versão corr. -- São Paulo, 2018. 92p.

[4] BRASIL, Tabelas PBE Veicular. Available at: < http://www.inmetro.gov.br/consumidor/tabelas_pbe_veicular.asp> Accessed on: 17 Jul. 2020.

[5] BRASIL, Ministério da Economia 2020. GRUPO DE ACOMPANHAMENTO DO PROGRAMA INOVAR-AUTO, Avaliação de Impacto do Programa Inovar-Auto - 2019 Available at <http://www.mdic.gov.br/images/REPOSITORIO/sdci/InovarAuto/Avaliacao_de_Impa cto_-_Inovar-Auto.pdf> Accessed on: 15 Jul. 2020. 